\title{
Partisan Scholarship in Technoscientific Controversies: Reflections on Research Experience
}

Vasilis Galis and Anders Hansson

\section{Linköping University Post Print}

N.B.: When citing this work, cite the original article.

This is an electronic version of an article published in:

Vasilis Galis and Anders Hansson, Partisan Scholarship in Technoscientific Controversies:

Reflections on Research Experience, 2012, Science as Culture, (21), 3, 335-364.

Science as Culture is available online at informaworld ${ }^{\mathrm{TM}}$ :

http://dx.doi.org/10.1080/09505431.2011.644783

Copyright: Taylor \& Francis (Routledge)

http://www.routledge.com/

Postprint available at: Linköping University Electronic Press

http://urn.kb.se/resolve?urn=urn:nbn:se:liu:diva-75219 


\title{
Partisan Scholarship in Technoscientific Controversies: Reflections on Research Experience
}

\author{
You've had no scientific training, so you can’t judge. I was a pretty good physicist in my time. Too \\ good-good enough to realize that all our science is just a cookery book, with an orthodox theory of \\ cooking that nobody's allowed to question, and a list of recipes that mustn't be added to except by \\ special permission from the head cook. I am the head cook now. But I was an inquisitive young scullion \\ once. I started doing a bit of cooking on my own. Unorthodox cooking, illicit cooking. A bit of real \\ science, in fact ...
}

Aldous Huxley, Brave New World

\section{Introduction}

In the past few years, the intensive development of science and technology has triggered public uncertainty and controversy, especially in domains such as health and the environment (Callon et al., 2009, p. 19). As technosciences have become more integral to social life, controversies about the development and application of, for example, environmental solutions and biotechnologies, have intensified. Consequently, questions arise about the neutrality of scientific method, participation in technoscientific knowledge production, and antagonisms and epistemological chasms between experts and laypeople - potential knowledge bearerswhen resolving science and technology disputes. Several academic traditions (e.g. philosophy of science, science and technology studies, feminist studies, Marxism, poststructuralism, and action research) have repeatedly addressed epistemological objectivity and/or partiality in the study of technoscientific controversies. What forms of partiality arise in studying technoscientific controversies? Can neutrality be attained in scholarly studies? On what epistemic grounds do researchers make methodological choices and with what consequences?

To answer these questions, this paper aims: a) to theoretically identify and discuss diverse accounts of partisan scholarship (i.e. de facto/overt, implicit/explicit, and mercenary/captured) and to indentify personal reconstructive politics and how it affects scholarship; and b) to explore and promote our own epistemological position as an example of particular types of partisan scholarship in two empirical areas of social concern seldom discussed in science and technology studies (STS): carbon dioxide capture and storage (CCS) technology for mitigating climate change, and the integration of accessibility provisions in constructing an underground metro system. 
The paper is organised as follows. The section 'Conceptual Approach: (STS) partisan scholarship' historically and theoretically discusses various takes on partisan scholarship in relation to topic choice, methodology, personal commitment, and use of findings in controversies. In the section 'Our politics', we discuss the politics of our partisan epistemology and how it affects our scholarship. Then, in the section 'Case Studies', we present the analysis of our personal experiences of technoscientific controversy in relation to partisan scholarship. Finally, in 'Conclusion: Towards a Partisan Epistemology', we discuss the implications of our analysis.

\section{Conceptual Approach: (STS) Partisan Scholarship}

The issue of political commitments embedded in scientific method is not new. However, science and technology were long entrenched behind opaque walls of objectivity, neutrality, and legitimacy. During modernity, the unquestioned authority of natural scientists and engineers allowed them to speak in the name of precision and academic validity regarding matters involving science and technology (cf. Collins \& Evans, 2002, p. 239). As a result, the dominant approach to investigating technoscientific controversies assumes that an objective scientific-technocratic rationality always underlies one side (often the experts') of a controversy (Engelhardt \& Caplan, 1987, p. 3; Scott et al., 1990, p. 474). In this context, reliance on expert knowledge is portrayed as a precondition for valid scientific research: an established and accountable aim of technoscientific praxis. This approach is equivalent to that of the elitist, impartial, rational, apolitical, and fully informed scientific community that judges based on its experience (Gouldner, 1976, p. 262; Engelhardt \& Caplan, 1987, p. 6).

Longino (1990) explains that, through the lens of a value-free or objective epistemology, science is considered to provide accurate descriptions of the facts of the natural world based on nonarbitrary, nonsubjective modes of inquiry (p. 62). In this framework, scientific education separates scientific method from the rest of the historical process (including politics) and helps produce naturalised scientific facts, free of opinion, belief, and cultural background (Feyerabend, 1975, p. 3). As a result, for several years many social science fields have tended to privilege objective scientific knowledge and expert authority. In the case of disability studies, biomedical experts and medical sociologists have been privileged (see Barnes et al., 1999), and in the case of sustainable environmental solutions, physicists, engineers, and energy experts (see Anshelm, 2000).

Relativist or social constructionist approaches (see e.g. the 'strong programme' in the sociology of science) claims that scientific knowledge production is far from autonomous, but that various political, economic, and social interests are deeply engaged in scientific practice (Bloor, 1976; Barnes \& Bloor, 1982; Longino, 1990; Haraway, 2001). However, and despite their epistemological dissonance, both positivist and relativist approaches agree that the values and political commitments of the social researcher should not impinge on scientific enquiry (Scott et al., 1990, p. 475; Collins, 1996, p. 239). For positivists, scientific knowledge production should be free of meaningless, value-based claims (Longino, 1990, p. 177), while for social constructivists, knowledge production must be protected by commitment to political values via the researcher's adoption of a symmetrical stance towards all sides of a controversy. According to this view, the starting point of any research effort should be one of symmetry, as only through symmetry can a researcher develop an analytical critique of science (Collins, 1996, p. 240). Both these approaches present the researcher as a social scientist and not as a partisan favouring any particular view (Bammer \& Martin, 1992, p. 219). 
However, in the 1960s and 1970s, the deifying of science and scientific work prompted a retreat from the rational premises of early twentieth century industrial capitalism to a belief system based on grassroots ideals. Following protests against the Vietnam War in North America and the May 1968 events in Western Europe, social movements and scientists gradually embarked on radical politicisation by questioning and deconstructing the political economy of science and who controls and benefits from it (Rose \& Rose, 1976). Looking back at the revolts against science, the juridical system, morality, the traditional approach to sexuality, and other contentious areas in the late 1960s and early 1970s, Foucault (2003) saw them as 'the insurrection of subjugated knowledges', constituting an autonomous and decentralised production of knowledge that ignores established scientific orthodoxy in seeking validity. To that point, science and technology had signified the authority to which all must submit (Gouldner, 1976, p. 261).

In reaction to technosciences' hegemonic position and in the framework of 'subjugated knowledges', (neo-)Marxist and feminist approaches to technoscience have advocated strong epistemological commitments to political action in the scientific occupation itself, in league with factory workers, local communities, and liberation movements (Rose \& Rose, 1976, p. xiv). Hilary and Steven Rose, for example, call for an emancipatory epistemology of science (Longino, 1990, p. 195; see also Rose \& Rose, 1976, 1979). In the same vein, Harding (2001) argues that emancipatory (or standpoint) epistemology ought to concentrate on gender differences that provide scientific advantages to those who can use them (p. 145). As well as accepting scientific objectivity in academic research, feminist standpoint theories also grant marginalised groups sole epistemic legitimacy. In this framework, scientific enquiry becomes a matter of assigning epistemological priority and displaying scientific solidarity with specific groups and beliefs. Feminist and Marxist partisan scholars aligned with specific marginalised groups have begun not only to participate in diverse technoscientific debates, but to establish and prioritise their agendas and methods as more credible and objective than those of orthodox scientists.

Nonetheless, the history of technoscientific disputes comprises more than facts and conclusions drawn from objective, politically prioritised, or socially constructed facts/agendas; it also comprises conflicting epistemological choices, economic priorities, and interpretations of facts (Feyerabend, 1975, p. 3). For example, disability activist and academic Colin Barnes (1996) argues that the structuring of academic research funding by governmental councils or independent/private charities and trusts and the introduction of market forces into the university system illustrate how academic scholarship is being ideologically shaped (p. 108). Biologist Garland Allen (1987) emphasises that economic and other class interests influence the character of technoscientific controversies, partly by shaping participants' views and partly by shaping research funding patterns (see also Engelhardt \& Caplan, 1987, p. 7). Martin (1998) explains that few scientific fields are truly autonomous, given the extent of military, government, and corporate funding. A criticism worth considering is that social analysis has tended to reproduce the hierarchies of scientific research fields, which in turn reflect the funding priorities of a political economy of science based on research supported by military and industrial lobbies (Woodhouse et al., 2002, p. 307). ${ }^{\text {i }}$

This kind of imbalance points to another: While a new system of elite research has emerged to allow specific scientists to enjoy greater influence in public and economic life, other scientists (often social scientists) continually find themselves receding from, or being pushed out of, the 
limelight and back into the obscure shadows of the organisational and professional structures from which they emerged (McGrath, 2002, p. 2). What we want to point out through this discussion is the epistemological power game and its implications for social scientists' choices within a technoscientific controversy. When researching, one claims authority over some area(s) of knowledge; in other words, one constructs credibility around one's research choices and methodology, claims the right to be heard, and eventually creates a dichotomy (via boundary work) between the legitimate scientific community (i.e. a core of experts) and illegitimate commentators (e.g. 'ignorant' laypeople and unscientific social analysts).

When investigating a controversy, for example, a researcher backed by a powerful social institution such as a university establishes himself/herself as an indispensable authority, an authority who must be consulted by specific actors in a controversy attempting to advance their interests. According to Collins and Evans (2002, p. 243), these confined groups of scientists (i.e. core scientists) possess monopolistic special rights and credible expertise to develop science and form consensus during a technoscientific controversy. As Callon et al. (2009) explain, this is the perfect crime: lay groups are expelled from configuring technoscientific issues, even if they are deeply concerned with and affected by them (p. 90).

Instead, we treat scientific practice and epistemological choice as parts of complex networks of practices and struggles subject to power and economic relationships (May, 1994 p. 115). The analyst, who is at the front lines of the technoscientific struggle, may be drawn in as a participant or used as a tool (Scott et al., 1990, p. 491). In line with Nelkin (1992), we argue that studies of controversies over technoscientific issues involve enquiring into the exercise of political control. Social analysts have never been isolated from the public and its politics, as they have always engaged with diverse groups when conducting research and have returned these findings to these groups (Burawoy, 2004, p. 257). Therefore, we claim that all research is partisan, and are interested in who controls, manipulates, claims, and establishes decisions, facts, and knowledge regarding the application of, for example, environmental technologies or the design of accessibility provisions, the rationale for doing so, and how we position our own research in these technoscientific disputes. ${ }^{\text {ii }}$

Several questions remain unanswered: What choices should an intellectual make? What struggles should a social researcher analytically support (May, 1994, p. 119)? What forms and structures of technoscientific knowledge production should be enacted? Inspired by Haraway's (2001) discussion of situated knowledges and May's (1994) of situated freedom (as a form of epistemological political intervention), we advocate a reconstructivist partisan epistemology for the study of technoscientific controversies that allies itself with struggles and social movements related to, for example, class, gender, race, the environment, and disability (cf. Martin, 1993, p. 251). Correspondingly, STS has a good track record of reconstructing technoscience-society relationships by reconfiguring lay-expert interactions, democratising technoscientific practices, and giving voice to critical diversity (Nowotny, 2007, p. 484; Webster, 2007a, p. 472).

A distinctive feature of STS research is that it has actively intervened in technosciences by enacting research issues as part of political processes of community, opinion, consensus, decision, and policy formation (Marres, 2007, p. 762; see also e.g. Wynne, 1989; Epstein, 1995; Jasanoff, 1997; Rabeharisoa \& Callon, 2002; Callon, 2003; Jasanoff, 2004; Melissa et al., 2005; Galis, 2006; Callon et al., 2009; Anshelm \& Galis, 2009). Nowotny et al. (2001) have suggested abandoning the concept of technoscience as delivering objective and reliable knowledge and instead turning to the production of socially robust knowledge (p. 201). 
Several STS scholars have conceptualised various participatory structures in which experts negotiate directly with laypeople to produce socially robust knowledge.

Callon (2003, p. 59) calls these structures 'hybrid forums'-cooperative research efforts that encompass not only discussions of technical or scientific choices, but also the exploration and exploitation of non-mainstream knowledge, i.e. expertise and experience that lie outside the frame of confined policy arenas. Similarly, Nowotny et al. (2001, pp. 201-214) mention 'agorae', namely, public spaces, the domain of neither market nor state, where various actors frame and problematise technoscientific issues and where what is produced as a solution is the product of negotiation. Wynne (2007) calls for disciplinary means of collective reflection by establishing STS as an alternative witnessing arena (p. 501). All these spaces call for a complete reopening and reconstruction of the policy-making space (cf. Webster 2007b, p. 609).

In an attempt to define different modes of politically engaged scholarship, Martin (1996) has introduced a taxonomy, which the present paper employs and develops, in which he lists three possible types of partisanship in social research: capture by other participants, de facto partisanship, and overt partisanship (see Table 1). In the first mode, the work of the social analyst is captured by other participants in a controversy, who find the analysis useful for their own purposes despite the researcher's intent. The research topic and methodology unconsciously coincide (or conflict) with the interests of certain participants in the controversy. The social researcher has no personal commitments to either side of the controversy, despite the efforts of certain participants to deploy the research findings for their own purposes. ${ }^{\text {iii }}$

In the second mode, de facto partisanship, the researcher's selection of topics and methods shapes the debate/dispute, without any avowed commitment to partisanship. In this case, the social researcher consciously chooses an analytical framework that may prejudge the use of his/her findings in the controversy. Partisanship is built into the assumptions underlying the investigation, without any requirement for overt political engagement. It is unsurprising that researchers' interests should be linked to their conceptual/methodological frameworks. Especially in cases of contemporary and controversial social problems, social analysts obviously tend to select research topics and methodological frameworks that are compatible with their professional fields and personal commitments (Bammer \& Martin, 1992, p. 220).

In the third mode, overt partisanship refers to open and acknowledged action research, in which the researcher links the processes of knowledge production and social change. The social researcher (as an overt partisan), identifies and participates in reconstructing the field of controversy. ${ }^{\text {iv }}$ In such cases, the selected topic and methodological framework allow for the involvement of members of the 'community'. The results of the research are intended to support participants in the controversy, such as social movements or proponents of technoscientific solutions (Martin, 1996, p. 264). Accordingly, several voices in research into social issues have questioned methodological impartiality and apolitical epistemology (Martin, 1993; Barnes, 1996; Jasanoff, 1996; Richards, 1996), while others go as far as to introduce an epistemology of politically engaged scholarship, reconstructive scholarship, action research, or public sociology (see e.g. Reason \& Bradbury, 2001; Woodhouse et al., 2002; Burawoy, 2004; Woodhouse, 2005; Greenwood \& Levin, 2007).

At this point, we would like to add a fourth category to Martin's taxonomy. Another take on partisan scholarship (and therefore another way to proceed) reflexively acknowledges the 
academic, economic, and political networks in which the social researcher makes epistemological choices regarding the research topic and methodological approach to the field studied, personal commitments, and the positioning of the research findings in the relevant debates. In many technoscientific disputes, the expert side is often represented by what we call mercenary scholars: actors appointed by the market or industry to university positions or private academic research who favour the technocratic sides of controversies. A devil's advocate could call such scholars 'partisans of the other side', who represent interests other than those of social movements."

Table 1. Research components and modes of partisanship. ${ }^{\mathrm{vi}}$

\begin{tabular}{|c|c|c|c|c|}
\hline \multirow{2}{*}{$\begin{array}{c}\text { Research } \\
\text { components }\end{array}$} & \multicolumn{4}{|c|}{ Modes of partisanship } \\
\hline & $\begin{array}{c}\text { Capture by } \\
\text { other } \\
\text { participants }\end{array}$ & $\begin{array}{c}\text { De facto } \\
\text { partisanship }\end{array}$ & $\begin{array}{c}\text { Overt } \\
\text { partisanship }\end{array}$ & $\begin{array}{l}\text { Mercenary } \\
\text { scholarship }\end{array}$ \\
\hline $\begin{array}{l}\text { Choice of } \\
\text { research topic }\end{array}$ & $\begin{array}{l}\text { unconsciously } \\
\text { overlaps with or } \\
\text { diverges from the } \\
\text { politics of the } \\
\text { participants in the } \\
\text { controversy }\end{array}$ & $\begin{array}{l}\text { conscious } \\
\text { choice of } \\
\text { research issue }\end{array}$ & $\begin{array}{l}\text { interventionist } \\
\text { investigations of } \\
\text { and support of } \\
\text { social movements, } \\
\text { social concerns, and } \\
\text { technopolitical } \\
\text { goals }\end{array}$ & $\begin{array}{l}\text { research projects } \\
\text { dictated by the } \\
\text { market or industry } \\
\text { to university or } \\
\text { private academic } \\
\text { research }\end{array}$ \\
\hline $\begin{array}{l}\text { Choice of } \\
\text { research } \\
\text { methods }\end{array}$ & $\begin{array}{l}\text { unconsciously } \\
\text { overlaps with or } \\
\text { diverges from the } \\
\text { intentions of the } \\
\text { participants in the } \\
\text { controversy }\end{array}$ & $\begin{array}{l}\text { conscious } \\
\text { choice of } \\
\text { methods }\end{array}$ & $\begin{array}{l}\text { participatory, action } \\
\text { research }\end{array}$ & $\begin{array}{c}\text { participatory, } \\
\text { mercenary research }\end{array}$ \\
\hline $\begin{array}{c}\text { Personal } \\
\text { commitment }\end{array}$ & no commitment & $\begin{array}{l}\text { no a priori } \\
\text { commitment }\end{array}$ & $\begin{array}{l}\text { solidarity with } \\
\text { members of the } \\
\text { community }\end{array}$ & $\begin{array}{l}\text { favours approaches } \\
\text { that pay for the } \\
\text { research }\end{array}$ \\
\hline $\begin{array}{l}\text { Use of research } \\
\text { findings in the } \\
\text { controversy }\end{array}$ & $\begin{array}{l}\text { participants in the } \\
\text { controversy } \\
\text { attempt to deploy } \\
\text { research findings } \\
\text { for their own } \\
\text { purposes in spite } \\
\text { of the researcher's } \\
\text { intention }\end{array}$ & $\begin{array}{l}\text { partially } \\
\text { shaped by the } \\
\text { choice of } \\
\text { topic and } \\
\text { methods }\end{array}$ & $\begin{array}{l}\text { intervention in } \\
\text { public debate }\end{array}$ & $\begin{array}{l}\text { intervention in } \\
\text { public debate }\end{array}$ \\
\hline $\begin{array}{l}\text { Involvement in } \\
\text { the controversy }\end{array}$ & $\begin{array}{l}\text { enrolment of the } \\
\text { researcher by } \\
\text { participants in the } \\
\text { controversy }\end{array}$ & $\begin{array}{l}\text { built into } \\
\text { assumptions } \\
\text { underlying } \\
\text { the inquiry }\end{array}$ & $\begin{array}{l}\text { intended and overt } \\
\text { involvement by the } \\
\text { researcher }\end{array}$ & $\begin{array}{l}\text { intended } \\
\text { involvement by the } \\
\text { researcher }\end{array}$ \\
\hline
\end{tabular}

Despite significant political engagement on the part of STS scholars, a lack of epistemic support of partisan research in technoscientific controversies is still the rule. STS analysis cannot be limited to a merely 'serviceable' or '(im)modestly witnessing' status (cf. Haraway, 1997; Webster, 2007a; Wynne, 2007). This is precisely the boundary that STS must cross if it 
is to become a reconstructive partisan scholarship or, as Wynne (2007) puts it, an alternativewitnessing STS aiming at ordinary, mundane social action (p. 501).

However, the point of partisan STS is not merely to accumulate deconstructive analyses of technoscientific controversies or, if conditions allow, to shape policy-making in the policy arena, but to democratically change and reconstruct the configuration of technosciences and to redistribute power relationships between experts and laypeople at multiple sites and in various vocabularies. Partisan STS research is oriented towards a more multifaceted world than that of the classical STS audiences (i.e. other STS scholars or policy-makers) (Woodhouse et al., 2002, p. 311). Nowotny (2007) argues that STS analysis demands a 'multilinguistic competence', that is, an ability to engage communicatively with a wide range of actors and communities. Once again, what side do we social analysts choose and why, and how do we disseminate our research findings to the public?

The politics of our partisan research answers the last question. It represents an effort to foster lay knowledge and marginalised scientific views in concrete technoscientific disputes either by analytically struggling alongside oppressed social groups (e.g. disabled people) or by promoting views (through launching critical studies) that challenge technocratic research agendas (e.g. credible critique of CCS). In the next section, we will present the politics of our partisan STS scholarship.

\section{Our Politics}

Within the epistemological pluralism of the social sciences, we all choose methodological traditions. This paper sides with scholarly traditions in STS that enrol social research for democratic social change, leading to more just and sustainable conditions for stakeholders (cf. Greenwood \& Levin, 2007, p. 3). We advocate 'scholarship aiming to support or stimulate social action' (Woodhouse, 2005, p. 203). Though terms such as 'justice' and 'democratic social action/change' can be defined and interpreted in various ways and from various standpoints, this paper does not attempt deep ideological debate on what constitutes good and objective definitions. After all, we can identify various crimes committed in the name of 'democracy' and 'striving for justice'. What prompts our research are the many methodological/epistemological crimes committed against lay knowledge in the name of objective scientific enquiry and the lack of reflexivity in orthodox scientific knowledge production.

We believe that STS partisan scholarship can also be part of the science and technology with which it engages, and that it does not necessarily have to form the basis for 'serviceable STS' in the policy arena (cf. Webster, 2007a, p. 473). Partisan scholarship as we perceive it does not entail drawing battle lines between partisan scholars and those who do not claim political alignment in their research (cf. Woodhouse, 2005, p. 200), or denying diversity of engagement among critical STS approaches (cf. Webster, 2007b, p. 609). On the contrary, we are aware that some scientists, social scientists in particular, are attempting to challenge the orthodox technoscientific status quo without avowedly partisan scholarship, but this does not automatically guarantee that they are also reordering the resolution of the controversy or that they are preventing the production of self-contradictory scientific facts, isolated from social concerns (cf. Feyerabend, 1975, p. 4). Therefore, and without any intention of underestimating the valuable and critical work of STS scholars who work within and among experts and policy-makers vis-à-vis the architecture and relationships of technoscientific policy-making (see e.g. Webster 2007b), our proposal for partisanship moves outside the 
secluded and discursive policy world of boardroom, architectural office, lab, EU corridors in Brussels, specific technical specialisations, etc.

Our STS analysis is inspired by and is part of the legacy and ontology of various social movements (including the labour, environmental, peace, feminist, anti-racist, anti-fascist, alter-globalization, and disability movements) and their struggles against the disqualification, oppression, and control of their local, public, non-expert, individual, or collective experiences/knowledge by epistemologically powerful experts in various technoscientific disputes. We are interested in social groups or researchers that participate in or are somehow concerned with technoscientific controversies. Examples of such groups are patient and environmental organisations, consumer and disability associations, or even researchers adopting social concerns or critical views, all influenced by the development of technosciences and seeking to intervene in configuring their politics. It is this potential critique of mainstream orthodox scientific standpoints, and not the epistemic culture of the scientific civil service (Webster, 2007a, p. 474; 2007b, p. 610), that our partisanship aims to ally itself with, articulate, and reconstruct in the context of the technoscientific disputes in which we are participating. As we will demonstrate in our cases, however, such an endeavour is not easy.

While some positivist and relativist researchers strive for scientific neutrality, symmetry, and objectivity, in line with Fujimura (1991), we 'want to take stands, to take points ... We want to construct concepts and theories to help some people win over others' (p. 223). What is at stake here is why some knowledge claimants have more credibility than others and on what grounds this credibility rests (McConkey, 2004, pp. 199-200). Our proposed partisan scholarship denies and surpasses the dualist epistemological dilemma of modernism, that is, being epistemologically objective for a neutral and value-free science versus being epistemologically objective for a politically engaged science. We advocate a situated epistemological choice for social scientists, who are part of the technoscientific controversies they study and who provide analyses to the social groups alongside which they struggle (May, 1994, p. 118). This does not mean that partisan researchers constitute avant-garde translators/representatives of social concerns in the secluded technoscientific policy-making 'room'; instead, they are Trojan horses that open the door of secluded policy rooms to the knowledges, needs, concerns, semantics, epistemologies, cultures, and languages of laypeople.

We refer to epistemic struggles against specific oppressive practices that allow other practices to be created (cf. May, 1994, p. 117). We believe that one way to advance a controversy is through a healthy, partial, and situated disrespect of the rules and of the actors who define them. Ferrell (2009) argues that 'blowing open the box of orthodox methodology begins a process of intellectual renewal' (p. 80). This does not constitute a one-size-fits-all epistemological toolkit or mean that we ideologically stand for all marginalised and oppressed social views. We advocate a partial methodological perspective enacted locally or regionally, enabling critical glances at sacred truths and allowing the production of knowledge less organised according to 'objective' scientific orthodoxy (cf. Haraway, 2001, p. 176).

This paper will advocate scholarly solidarity or communication with stakeholders and oppressed social movements in technoscientific controversies through our own situated epistemological position (or political agenda) or, as Burawoy (2004) puts it, we will give stakeholders 'counter-hegemonic possibilities' (p. 270). We identify two concrete reasons why social scientists should align their research with these groups: 1) to promote 
heterogeneity in the resolution of technoscientific disputes - the domination of orthodox scientific experts in controversies does not stem solely from blind confidence in science, but also from commitment to a homogenous network of relationships that makes orthodox scientific knowledge inevitable (May, 1994, p. 143); and thus 2) to address and support research agendas, critical views, and particular interests ignored by market forces, the political economy of academic research, government-funded research councils, dominant assumptions and values, etc., but that could reorder the production of scientific facts in a way that serves the interests of social groups.

Accordingly, citing empirical examples, we will demonstrate that selecting specific research agendas and adopting a somewhat partisan approach in conducting our studies may help counteract existing biases in case analysis and development, and allow oppositional actors to articulate their viewpoints. We are interested in the politics of research methodology - why and how some human perspectives win over others in constructing technologies and facts (cf. Fujimura, 1991, p. 222). We will respond to the debate on epistemological struggles by presenting methodological conflicts and dilemmas that we encountered during our $\mathrm{PhD}$ fieldwork. Each case will be presented in first person singular, since we individually selected our material and organised our fieldwork during our doctoral studies. Nevertheless, we jointly analysed the material for this paper in discussions. While the two cases constitute very different examples, they are compatible in many respects since they both demonstrate why partisan research agendas can be a pragmatic and inevitable option. Both empirical cases call for the more democratic configuration and resolution of technoscientific controversies.

\section{Case Studies}

As already mentioned, we empirically focus on two earlier investigations to cast light on our choice of research topic and method, personal commitment to the fields studied, use of research findings in the controversy, and positioning of results in the debates. Both controversies presented here involve oppositional interests, several expert and non-expert actors, attempts to gain public acceptance, and diverse methods to ensure scientific legitimacy.

The first study (Hansson, 2008) problematises a new technology for managing climate change, namely, carbon dioxide capture and storage (CCS). CCS has quickly gained significant support from influential actors, but has also prompted criticism and concern. The study critically analyses the scientific and political efforts supporting the view of CCS as a rational and viable solution to climate change problems. As the research progressed, partisan elements appeared - both intentionally and unintentionally. The second study (Galis, 2006) discusses the construction of the new underground metro system in Athens. The construction entailed numerous preliminary studies, various public organisations involved in its development, and a number of controversies regarding its design. One of these controversies concerned accessibility for disabled people. The question of whether or not to integrate accessibility provisions into the metro design engendered disputes concerning budget (accessibility provisions raised costs), architecture (disability organisations sought to participate in the design), and system usability.

Despite the different natures and contents of the two cases, they raise similar concerns regarding unbalanced epistemological positions during negotiations over sociotechnical systems such as CCS and the Athens metro, and call for a somewhat partisan epistemology. Taken together, the two cases cover partisan epistemological choices aiming at a radical 
reordering of the research activity. ${ }^{\text {vii }}$ Concretely, the first case constitutes a deconstruction of the orthodox scientific, political, and economic establishment that is supporting, with ambiguous methods, the launch of a controversial environmental technology. The researcher thoroughly reviewed techno-economic reports, mass media articles, political documents, and interviews to scrutinise the basic assumptions, various standpoints, scientific claims, and rhetoric associated with this technology.

The second case exemplifies a reconstructive epistemological choice. By openly situating his scientific and epistemological solidarity with the Greek disability movement, the researcher attempted to participate in the controversy and reconstruct/reorder the technoscientific debate regarding disability and accessibility in Greece. The investigation of the two cases embodies contemporary disputes regarding who has the right to participate in, decide on, and act on the configuration of technosciences. We will participate in the debate on epistemological choice by presenting our personal experiences in controversial and politically engaged scholarship, as they evolved during our $\mathrm{PhD}$ fieldwork.

\section{Case I: Deconstructing CCS}

CCS is a technology applicable mainly to large-scale fossil fuel point sources, such as coal power plants, where it captures $\mathrm{CO}_{2}$ from flue gases and disposes of them in geological formations. As the only mitigation option enabling the prolongation of a fossil fuel-dominated energy system in a carbon-constrained world, CCS has attracted considerable attention and resources from concerned industries. The Intergovernmental Panel on Climate Change (IPCC) claims that CCS could account for $15-55 \%$ of the cumulative worldwide mitigation effort up to 2100 , and reduce the costs of stabilising $\mathrm{CO}_{2}$ concentrations by $30 \%$ (IPCC, 2005). CCS has therefore recently been accepted by numerous influential industries, politicians, and academics as an important, reliable, safe, and even necessary tool for mitigating climate change, despite the fact that it has not yet been commercially tested and involves many environmental impacts and trade-offs, both known and unknown (Hansson, 2008; EC, 2008; IPCC, 2005).

The stance of environmental non-governmental organisations (ENGOs) regarding CCS varies: several are supportive, some oppose it, and many only reluctantly accept it. CCS is contested because of economic, environmental, and ethical concerns. Briefly stated, a number of critical issues are touched on in the CCS debate. First, CCS implies high costs, as it significantly increases both the construction and operating costs of power plants. Second, CCS implies the long-term disposal of huge amounts of waste, and may compete with renewable sources of energy since it would prolong and perhaps deepen the fossil fuel 'lockin'. Third, CCS arouses scepticism, not only due to risks of sudden leakage, seepage, acidification, and minor earthquakes, but also because of ethical and public concerns, such as inter-generational risk transfer and exploiting developing countries as 'guinea pigs' when storing $\mathrm{CO}_{2}$ (de Coninck, 2008; IPCC, 2005; Rochon, 2008).

The interest of large fossil fuel-related corporations in CCS is self-explanatory, since CCS is considered the only option for maintaining a heavy reliance on fossil fuels in a carbonconstrained future. Interestingly, many ENGOs also support the idea of developing CCS, despite their inherent strong resistance to coal power. Thus, CCS is increasingly labelled a 'sustainable solution' or 'clean coal technology' (Ramirez et al., 2008; Tjernshaugen, 2008). However, in scratching the surface, one finds even more potentially controversial issues. Several aspects remain unresolved and unknown, while various actors are simultaneously 
attempting to establish the benefits of CCS as an objective and scientifically viable solution. Why did I choose to examine the CCS issue?

\section{Choosing the Research Topic}

In 2003, I began working on my doctoral thesis, focusing on the politics of CCS. It was obvious to me that CCS was far from a strictly scientific issue: it is not an issue with clear-cut answers, as it is often portrayed in the public by its proponents. Instead, CCS is a complex sociotechnical issue with far-reaching political, economic, and scientific implications. The starting point of my research was to deconstruct the politics of CCS, which is overwhelmingly coloured and managed by CCS proponents. It was this kind of optimism surrounding CCS that piqued my interest and curiosity about the scientific, epistemic, and social grounds on which the over-optimism regarding CCS rested. Curiosity and the challenge of opposing mainstream technocratic research in the field strongly influenced my choice of research topic. Moreover, working in a social sciences university department provided me with relative organisational impartiality with respect to CCS, and an absence of commitments to anyone involved in the CCS debate. However, and as will be demonstrated later, one can as easily reinterpret my position as the other participants' positions in the controversy.

\section{Choosing Research Methods}

My initial stance towards CCS development was that it was unusual and intuitively seemed risky and futuristic. On further investigation, I found very little criticism of it, especially from members of the scientific community. This lack of critical perspectives informed my methodological choices and encouraged me to critically analyse the science and politics supporting CCS development. My investigation initially centred on scientific and policy documents treating CCS. At the same time, I began identifying possible informants within a complex network of scientists, policy-makers, and the public. A major potential barrier to CCS development, as emphasised in the IPCC Special Report on CCS, is its lack of societal acceptance (IPCC, 2005). The history of energy politics provides the debate with numerous examples of intense public controversies that have halted the large-scale implementation of energy technologies. In the aftermath of these previous controversies, the power industry has emphasised the importance of social acceptance. In public surveys, CCS often emerges as one of the least desired options, together with unusual geo-engineering schemes, such as fertilising the oceans with iron. That being said, most people have never heard of CCS (Hansson, 2008).

Industry has huge incentives to reverse this lack of social acceptance, especially since several disposal projects have already been halted by social protests. It also has the economic and intellectual capacity to do so, by employing methods of scientific authority. These methods have emanated from attempts to persuade ENGOs and social scientists to conduct research into public perceptions of CCS, and into how to influence public opinion, present information, and initiate education campaigns concerning climate change and its technological solutions. In this context, social science is reduced to uncritically supporting and propagating facts already produced by industry or by CCS proponents in academia (see Ashworth et al., 2010; Malone et al., 2010). This downgrading of social analysis influenced my methodological approach. Accordingly, early in my research, I critically examined the CCS acceptance research and concluded, among other things, that it was very normative and in many cases aimed at developing methods for convincing people that CCS is worth striving for, rather than at fostering public debate regarding the uncertainties, values, and wider context of CCS. 
The merits and performance of CCS technology are often presented in the mass media and in scientific reports as if they were risk-free scientific facts or that all implementation problems are technically manageable. Knowledge of CCS is produced and made public mainly by certain groups, that is, CCS experts who possess the right of interpretation, hence the positive framings of CCS outweighs the negative (Mander \& Gough, 2006; Hansson, 2008) and the scientific competence to discuss CCS. Natural and social scientists, based, in some cases, on 'indisputable data', were enlisted to gain knowledge of how to persuade the public to accept CCS (Ashworth et al., 2010). The dominant perspective in acceptance studies explicitly or implicitly presenting facts regarding CCS influenced my methodological choice also to investigate how these facts were constructed by science and their political context. Therefore, as a second step, I critically reviewed some of the scientific grounds on which CCS rests; more specifically I scrutinised assumptions regarding the technology's future characteristics, impact on the energy system, and development.

For example, since CCS does not exist commercially, its costs are the subject of scenarios, estimation models, calculations, and prognoses, which constituted an analytical focus of my investigations. In these models, the input variables for CCS have recently been demonstrated to be very volatile or disputable. Many gaps and uncertainties exist behind this wealth of information: the studies largely reference data from just a few sources, which often have common origins (Anderson et al., 2007; Hansson, 2008; Page et al., 2009). According to Anderson et al. (2007) and Page et al. (2009), most CCS development is undertaken in the private sector and confidentiality agreements make much of the information on CCS unavailable to the public and to independent researchers. Anderson et al. (2007) draw a general conclusion that economic data on CCS are insufficiently robust for decision-making.

Despite this uncertainly, economic data on CCS were considered robust enough for information campaigns and decision-making, even though costs have proved to be very volatile the past few years and total costs are based only on estimates. Thus, invoking scientific authority in applying incomplete data to policy-making could lead to the development of pro-CCS communication and information strategies, which do not make for transparent and reflexive scientific methodology. However, those disseminating these data never claimed that they intended to be transparent or reflexive. In contrast, I claim that it is crucial that science be transparent, especially when the investigation object is of social importance and involves truths and consequences that are or may be contested.

\section{Personal Commitment}

According to both its proponents and opponents, the 'window of opportunity' for implementing CCS is only a few decades or, in some cases, only a few years. It may even be too late in some instances, due to the high construction rate of unabated coal power plants and the need for carbon dioxide injection to enhance the recovery of oil in soon-to-be-depleted oil fields. In the case of CCS, the requirement for sound scientific facts to provide a basis for rational policy-making is impossible to fulfil. I am not advocating reconstructing alternative truths; instead, my standpoint in this case is that invoking truth as the goal of science is distractive, manipulative, and perhaps a diversion from real, pressing tasks (cf. Funtowicz \& Ravetz, 2003). Nevertheless, and invoking the urgency of implementing technologies to manage climate change and save the planet, pro-CCS scientists believe they can legitimately take a stand and manipulate people's opinions (see also Hansson, 2008). In the following, I will argue that this presents a chance for social scientists and partisan scholarship to counterbalance this powerful apparatus of industrial and business interests that, in various 
ways, favours CCS. However, how to achieve that was not obvious to me at the beginning of my research.

Early in my $\mathrm{PhD}$ project, a large energy corporation (a world leader in developing a specific carbon-capture technology) approached a colleague and me about cooperating on research into public acceptance in the vicinity of a proposed CCS plant. In my view, this offered me an opportunity to promote deliberation on a specific CCS project. Our project started with a few meetings and some ideas were outlined. The company offered financing, which I rejected because I was already fully financed by the Swedish Energy Agency (which at the time had no stake in CCS) and because I wanted to continue working as independently as possible in relation to funding bodies with vested interests.

It was important for me to choose the research topic and investigative methods independently. In the meantime, I was conducting another interview study with a fellow $\mathrm{PhD}$ student at a technical Swedish university department with a long history of close cooperation with Sweden's largest utility companies. Among the interviewees was the project leader of the aforementioned CCS project (a core expert). The interview was straightforward, probably because the project leader felt comfortable having what he considered two CCS supporters on the other side of the microphone. The interview resulted in a report in which the project leader, among others, was quoted.

After publishing our report and investigation results, the company's CCS project leader withdrew support and cancelled our participation in the acceptance project. He was quoted as stating: 'there was no potential for renewables'; 'laypeople are misinformed and ignorant regarding energy-related issues'; and 'CCS is totally safe and faces no insurmountable technological barriers'. This response did not correspond to the company's new image of being a corporation involved in open dialogue with society. Although at this early stage I had no intention of becoming actively committed in the CCS controversy, the company had already categorised my research findings as 'partial' (probably a common response to any threatening research).

Use of Research Findings in the Controversy: Mercenary versus Partisanship Scholarship To add another level of complexity to the account, the same project leader is also an adjunct professor at a prominent Swedish technical university department. The phenomenon of adjunct professors has recently become an issue of public debate in Sweden. Adjunct professors are financed by actors external to the university (often corporations or private research funds); this unique case of mercenary scholarship ${ }^{\text {viii }}$ provides grounds for criticism regarding the lack of openness in the academic appointment system, the ethics and goals of involved funders, and the omission of the prefix 'adjunct' in many cases (Atterstam, 2009; Nilsson \& Atterstam, 2009).

CCS researcher Reiner (2008) emphasises the need to bridge 'communication gaps' arising from a lack of educational materials, communication methods, and credible messengers (such as ENGOs or academics) regarding CCS technology. Academics in particular, according to Anderson et al. (2007), constitute more trustworthy and credible sources than do industry. In line with this, the project leader emphasised his academic affiliation on several occasions, to bolster his scientific credibility. While lack of credibility is a general problem highlighted in the CCS acceptance literature, the adjunct professor/project leader in my case is lobbying for CCS through direct contact with politicians and civil servants at the EU level, exploiting his professor status (sometimes without mentioning the 'adjunct' prefix). Despite his 'neutral' 
academic status as an adjunct professor, the project leader is taking a clear stand in support of CCS. He uses his status to inform the public and politicians about 'objective' matters concerning CCS, while simultaneously establishing scientific legitimacy for his claims, his goals, the goals of the corporation he works for, and CCS mobilisation. My implicit aim was to scrutinise the CCS proponents' over-optimism and epistemic orthodoxy by mapping and synthesising the delimited critical CCS landscape and deconstructing the scientific efforts of mercenary scholars who support CCS.

\section{Involvement in the Controversy}

In contrast to the above example, I am working from a de facto partisan position: without claiming objectivity for my research and how I present it or my commitment to CCS opponents, I am attempting to deconstruct unquestioned assumptions while simultaneously highlighting and reconstructing marginalised views of them. My contribution to the debate is to question hegemonic scientific assumptions regarding CCS by showing epistemological solidarity with the under-researched problems and marginalised critics of CCS. The dissertation received considerable mass media attention and was framed as criticising CCS. CCS-sceptical ENGOs encouraged me to write debate articles opposing CCS in major newspapers and offered me funding to write a paper addressing politicians to demonstrate that CCS is not an appropriate technology for mitigating climate change.

Obviously, the ENGOs already regarded me as on their side, since I had critically analysed the technology, the proponents of which vastly outnumber the critics, and stated that there is probably over-optimism regarding the potential of CCS. I did not write any articles or papers on the subject to avoid becoming captive in the controversy, nor did I make any proactive attempts to make my voice heard in the mass media. Not surprisingly, considering how my research was portrayed in the mass media, I was treated as a CCS opponent, so, like it or not, I was captured. Again, my epistemological standpoint had been categorised as partisan. On the other hand, neither science/business nor ENGOs could claim neutrality regarding CCS policy-making.

\section{Case II: Reconstructing the Athens Metro}

I began my doctoral studies in autumn 2001. My thesis research concentrated on the accessibility provisions of the new Athens underground metro system and the involvement of disability organisations in its design and construction process. I recorded interactions and negotiations between politicians and engineers involved in the project, and between them and members of the Greek disability movement. These negotiations often revealed tensions and conflicts deeply rooted in Greek society regarding the rights of disabled people, the involvement of politicians in accessibility issues, and the scientific authority of engineers and architects in designing the Athens metro system.

The development of the metro project embodied contemporary controversies regarding who has the right to participate in, decide on, and act in configuring the built environment. The study followed the Greek disability organisations and their non-mainstream knowledge production alongside the metro project: disability groups evolved from being weak actors unable to influence socio-political configurations to actors who successively attracted the attention of public administration, political organs, Greek parliament, and the company building the metro. Alongside this development, the metro system changed from being designed without any provisions for disabled people to being constructed as fully accessible infrastructure. 


\section{Choosing the Research Topic}

Researcher identity also influences the choice of epistemological standpoint. Burgess (1984) notes that social researchers who study their own societies may find their personal experience of particular roles and social settings significant to their research (p. 32). In my case, maintaining a neutral or symmetrical epistemological stance as a researcher (with specific personal, political, and intellectual identities) was not an option when studying a sociotechnical project in my home society. In other words, the process of formulating the topic, research questions, and methodology were the result not only of theoretical and intellectual enquiry, but also of my personal interests. While I was a stranger to disability issues and an indifferent Athens metro passenger before conducting this study, certain aspects of my personal background awakened my interest in how the metro system became accessible and the implications of this process for people with disabilities in Athens.

One of my friends, Nikos Perdikaris, is a disabled person who uses a wheelchair. My interaction with Nikos greatly informed the study formulation, and discussions with him provided me with ideas on how I could operationalise it. At the same time, Nikos is an active member of the Greek disability movement, which meant that he provided me with several contacts with informants and inculcated me with a partiality towards disabled people ${ }^{\mathrm{ix}}$ and their political agenda (Galis, 2006). In other words, Nikos was a source of partial, locatable, critical knowledge of disability in Greece, which provoked what is called 'solidarity' in political terms or 'shared conversations' in epistemology (cf. Haraway, 2001, p. 176).

\section{Choosing Research Methods}

However, in conducting the study, I faced methodological and epistemological dilemmas. Being able-bodied and researching controversies concerning disability can be complicated, in the sense that 'those conducting disability research for a $\mathrm{PhD}$ or other qualifications cannot resist demands for their projects to be shaped in ways which are not only a waste of time, but also are oppressive, both of themselves, and of disabled people being studied' (Moore et al., 1998, p. 20). Thus, a key point in the methodological framework that I intended to develop and apply was the choice of an epistemological standpoint: Why do disabled people in Greece deserve solidarity and support from academic scholarship?

The history of disability issues in Greece provides a relevant answer. Until the 1980s, a mixture of neglect and religious/charity concern with deep cultural roots had characterised disability issues. Disability was perceived as a disease to be cured or dealt with by institutionalisation. The disabled were outsiders in Greek society who were unable to influence socio-political configurations, while the government and church treated them as charity objects or patients. By formulating a common political agenda, in combination with the reforms that the first socialist government launched in the early 1980s, disability organisations successively succeeded in promoting their claims and making their voices heard. However, certain political developments, such as the return of the conservative party to office at the start of the 1990s, interrupted the political momentum that disability organisations had developed in the 1980s and downgraded their social role.

In the mid 1990s, the return of the socialist government re-established the importance of disability issues in public administration. The initiation of two cross-ministerial committees that worked on disability and accessibility issues and included both experts and disabled people strengthened the political and scientific roles of disability organisations. These committees focused on ratifying obligatory measures against physical and institutional barriers, taking into consideration the accumulated experience and knowledge of the disability movement. The committees produced broad definitions of disabilities that had a unique value, 
since they did not focus only on people with permanent impairments, but also, for example, on the elderly, pregnant women, children, and the temporarily injured. These notions of 'disability' referred to much of the population and increased demand for the construction of accessible infrastructure (Galis, 2006).

However, the participation of disability organisations in various technoscientific arenas, such as the construction of the Athens metro system, was never formally mandated by the Greek state. Recurrent changes in relevant ministerial positions (not only between socialist and conservative regimes, but also between politicians belonging to the same party during cabinet shuffles) disrupted continuity in the approach to disability issues, sabotaging the democratic participation of disabled people in the sociotechnical arena. Despite important political gains, such as the establishment of the Greek National Confederation of Disabled People as a unifying forum for articulating disability issues and providing representation in political decision-making spheres, disabled people and their organisations have not succeeded in institutionalising their (counter-hegemonic) knowledge production as political praxis. Facing this kind of vacuum in disability politics in Greece, my research effort automatically became overtly partisan, since it was 'contaminated' from the outset with implanted political motives related to the disability agenda that aimed to support specific political goals.

\section{Personal Commitments: Epistemology of Partiality}

The study aimed to contribute to ongoing debate concerning issues of exclusion and discrimination against disabled people by acknowledging that 'disabled people, as a group, are in an oppressed position' (Bennett, 2002, p. 811). This constitutes a concrete recognition that disabled people are ranked low in the hierarchy of scientific credibility, as well as a conscious methodological choice with specific implications: the project included elements of an emancipatory research paradigm. Such a paradigm requires that the researcher be strongly committed to the interests and needs of disabled people. At the same time, the emancipatory researcher engages in political action by changing the relationships involved in research production, i.e. the power relationship between researchers and the researched (French \& Swain, 1997, p. 28), or as Martin (1996) puts it, 'those who are commonly the objects of the research instead become the subjects' (p. 264). What did this imply for my method of collecting and analysing the empirical material?

During my fieldwork, to cancel out what I perceived as the social exclusion and epistemological downgrading of disabled people, my disabled informants were assigned an active methodological role and were not treated as 'the Other'. I attempted to follow, present, and support my disabled informants both as they attempted to transform the Greek society and as they sought to influence the construction of the Athens metro, since 'actors know what they do and social scientists have to learn from them not only what they do, but how and why they do it' (cf. Latour, 1999, p. 19). Nevertheless, researching disability implied that I was undertaking research that could be of 'practical benefit to the self-empowerment of disabled people and/or the appraisal of disabling barriers' (Bennett, 2002, p. 816). Thus, I was committed to disability politics and introduced more 'vulnerability' into my research project in terms of disability issues; that is, I openly attempted to reconstruct the balance of relationships between experts and disability organisations in the design of the metro. 


\section{The Social Researcher's Involvement in the Controversy}

I am not a disabled person myself, and even though scholars aligned with the emancipatory paradigm claim that able-bodied researchers can contribute to the 'demystification of structures and processes that create disability', my able-bodied position does not allow the adoption of an emancipatory research paradigm standpoint in every respect. Moreover, those who read the study carefully will notice that I am not uncritical of the methods of disability organisations and their advocates. Nevertheless, I am fully aware that my arguments and epistemic/scientific status can be used from one side of the controversy I studied.

Accordingly, several disabled informants who represented disability organisations perceived my work as an avenue for expressing complaints regarding the oppression that disabled people face in Greece, promoting their claims and demands, and making their voices heard. In other words, these informants attempted to deploy my work in their efforts to achieve a better hearing for their claims. This constitutes a conscious methodological choice made in accordance with my partisan research agenda and emancipatory research paradigm. What I advocate is more democratic participation in the processes that help configure the built environment as well as more policy initiatives to reduce disabilities (cf. Richards, 1996, p. 344). In that sense, the researcher's involvement in the controversy situates the researcher's partial position from which the research effort is produced.

However, my overt partisanship and my status as a social scientist made certain informants sceptical of my research or prompted them to refuse to participate. Three categories of ablebodied informants were particularly sceptical of my research, namely, a few engineers and architects working for the supervising company Attiko Metro, several public administrators working for various ministries, and a small number of politicians involved in the project. One characteristic episode during my fieldwork illustrates this kind of scepticism. I was to interview one of the architects working on accessibility facilities at Attiko Metro. When I entered the architect's room, I was welcomed with a big smile and a sense of shared understanding, which reduced my nervousness. The old man, almost hidden behind stacks of architectural illustrations and pens, rubbed his hands with satisfaction and asked me: 'So you are doing your PhD in Sweden?' 'Yes', I answered in a fairly relaxed manner. 'Architecture?' he asked again, winking at me. I froze and did not know what to answer. Finally, I answered 'no' and attempted to describe my background, what interdisciplinary research implied, and the politics of my study. I knew, however, that once I replied 'no', I had somehow lost his confidence. His facial expression changed immediately and the initial sense of shared understanding was lost. I had been irreversibly degraded in the scientific hierarchy within seconds. 'OK, then, ask me what you need to know and please do it quickly because I have many things to do', he told me impatiently. All of a sudden, I became an ignorant social researcher who was just wasting his time with 'unscientific' questions. The second and final shock came when I asked him whether I would be allowed to tape our discussion. He looked very confused and suspicious. 'No, I do not do stuff like that', he answered. 'I do not understand why you are doing this. These questions are not important; people with disabilities did not contribute much to the implementation of accessibility. It was we, the engineers and architects, who contributed to the realisation of accessibility in the system' (Galis, 2006).

That was the summary of our discussion, more or less. The old architect disqualified me from the valid scientific community and thereby scorned my research efforts, since I did not belong to the epistemic culture that corresponded to his academic/scientific ideals. At the same time, he disqualified non-orthodox knowledge as inadequate while accentuating the role of the experts. He was completely wrapped in an orthodox 'scientific' position, and everything else, 
including my own research and the contribution of disabled people, constituted unscientific, irrational, unproven, and mistaken claims (cf. Scott et al., 1990, p. 484). This was not the only time during my fieldwork that I was confronted by such scepticism. Some of the able-bodied public administrators I attempted to interview either refused to participate or refused to let me record our discussions. Those who agreed to be interviewed literally interrogated me as to my identity, role as a researcher, and what I intended to do with the collected material. They were extremely suspicious of both my questions and myself, but above all, of my recorder. As a result, I faced difficulties acquiring the information and data that I needed, at least initially.

This sort of ongoing exclusion of my research from the controversy was due partly to the fact that the Greek public sector representatives were unfamiliar with qualitative research methods and partly to the perceived limited impact of disability organisations on the controversy. The methodological culture of social research (especially of social research that is aligned with social interests) was completely foreign to public servants, making my work extremely complicated. In this context, being a social researcher who chose to study technical infrastructure and to support a social movement considerably weakened the credibility of my research and, therefore, my status as a researcher in the field. In their eyes, I was an obscure activist with inadequate scientific credibility, despite the fact that I had done my homework on the technical and architectural grammar and semantics. Once again, this constituted a perfect white-collar crime: authoritative public administrators expelled both a social researcher and a movement bearing counter-hegemonic knowledge from the configuration of a technical system, with the assurance that the experts were adequately dealing with accessibility issues. In this controversy, there was no space for 'interactional expertise' (Collins and Evans, 2003, p. 448) or 'serviceable STS'. Therefore, both my disabled informants and I perceived my work as an initiative against Lethe: a form of equipoise to the hegemony of indolent politicians, overconfident engineers and architects, and sceptical bureaucrats in the configuration of disability politics.

\section{Conclusion: Towards a Partisan Epistemology}

This paper has reviewed, both theoretically and empirically, various partial epistemologies that arise in studying technoscientific controversies. Concretely and unlike relativist and positivist methodological traditions, we took 'sides' in the controversies we studied: we wanted to demonstrate solidarity with the Greek disability movement and to deconstruct the epistemic hegemony related to the launch of CCS. This does not imply that the methods for choosing sides were simplistic and uncritical, or that we normatively argue against nonpartisan scholar standpoints. After all, we agree that there is no uniquely objective position from which to study, advise, or intervene in technoscientific controversies (Woodhouse et al., 2002, p. 311). Nonetheless, our partisan epistemology had concrete consequences for the topic of the study, the research methods, our commitment to the controversy, and the use of research findings by various concerned groups.

In Table 2, we summarise the motives underlying our choice of research topics and methodology, our personal commitments, the use of research findings in the controversies, and our involvement in the two cases presented in the previous section. Our partisan approach to the cases presented here includes an awareness that we cannot deny epistemological partiality (coloured by ideological/scientific scepticism or solidarity) in choosing research topics. Specifically, we cannot deny the social researcher's suspicion of, in the first case, the mainstream framing of CCS, non-transparent relationships between business interests and academia, as well as, in the second case, epistemological hierarchies in the design of the 
metro system and the downgrading of the non-mainstream knowledge of the Greek disability movement.

\begin{tabular}{|c|c|c|}
\cline { 2 - 3 } $\begin{array}{c}\text { Table 2. Research components and } \\
\text { modes of engagement. }\end{array}$ & \multicolumn{2}{c|}{ Modes of engagement } \\
\cline { 2 - 4 } Research components & CCS & Athens Metro \\
\hline Choice of research topic & $\begin{array}{c}\text { curiosity, asymmetrical } \\
\text { presentation of CCS }\end{array}$ & personal contacts \\
\hline Choice of research methods & $\begin{array}{c}\text { epistemic solidarity, critical } \\
\text { analysis of CCS proponents }\end{array}$ & $\begin{array}{c}\text { emancipatory research } \\
\text { paradigm }\end{array}$ \\
\hline Personal commitment & $\begin{array}{c}\text { no organisational } \\
\text { commitments, not engaged in } \\
\text { CCS development }\end{array}$ & $\begin{array}{c}\text { solidarity with the disability } \\
\text { movement }\end{array}$ \\
\hline $\begin{array}{c}\text { Use of research findings in the } \\
\text { controversy }\end{array}$ & $\begin{array}{c}\text { counterweight to CCS over- } \\
\text { optimism, mapping the } \\
\text { critical CCS landscape } \\
\text { of disabled people from } \\
\text { the non-mainstream knowledge } \\
\text { of the disabled }\end{array}$ \\
\hline Involvement in the controversy & de facto partisanship & $\begin{array}{c}\text { counterweight to the exclusion } \\
\text { overt partisanship }\end{array}$ \\
\hline
\end{tabular}

The choice of topic also affected the choice of methodology. Accordingly, we consciously stopped playing by orthodox methodological rules and introduced 'vulnerability' into our research. That is, at some point we de facto or overtly chose to be partial, to conduct our studies from an emancipatory/situated epistemological standpoint in order to reorder the epistemic status quo of the controversies studied and to analytically reconstruct/promote social interests, science, and technology in a more socially useful and democratic way. In the CCS case, the chosen topic and methodology were translated into a de facto partisanship. The researcher chose to explore and critically discuss scientific and business interests that were attempting to promote acceptance of CCS technology. The researcher, without an avowed commitment to either proponents or opponents of CCS, deconstructed unquestioned facts while simultaneously supporting marginalised CCS critics. The research findings received considerable attention and were used in the controversy in favour of CCS critics. ENGOs attempted to capture the researcher by encouraging him to author debate articles opposing CCS.

In the Athens metro case, avowed partisanship shaped the topic and research methodology in line with the emancipatory research paradigm and with intellectual solidarity with the Greek disability movement. The researcher had an intellectual duty to expose and challenge discriminatory practices against disabled people perpetuated in various technoscientific and political arenas, to criticise systematic disruptions and gaps in public administration and in existing legislation concerning disability and accessibility issues, and to advance the participation of disabled people in the technoscientific arena. In several cases, the concerns, ideas, demands, or even knowledge of non-elites have been under-represented or neglected in the study and resolution of technoscientific disputes (Woodhouse et al., 2002, p. 302). Could 
partisanship be entirely avoided in these particular cases? Even if the researchers in these two specific case studies had chosen to abstain from a partisan epistemology, other participants in the controversies could hardly have been described as neutral or objective.

As demonstrated, certain actors often employed mercenary scholarship, wielding academic authority to foster acceptance of the controversial technology. As our analysis demonstrated, the involvement of certain experts in business or other interests weakened their profile as reliable producers of objective scientific facts. However, these experts did not raise these issues in the technoscientific debate in the case of either CCS or the Athens metro system. Quite the opposite: Their access to political power centres and economic resources, as well as their higher status in the scientific hierarchy of credibility, allowed these experts to disqualify or-directly or indirectly - exclude our voices and findings from debates on the development of specific CCS projects or on the participatory development of the Athens metro without exposing their vested interests.

What both predecessors in the partisan scholarship realm and our cases indicate is that partisan research is far from easy to conduct. On the contrary, this approach had concrete consequences for our research status and perceived scientific credibility. Woodhouse et al. (2002, p. 301) argue that stated epistemic partisanship may strike some research traditions as threatening good scholarship. In our cases, experts, who were also informants, involved in the studied controversies categorised our work as unscientific or threatening. This constituted our sociological entry to the field, not from the front door but through the back door or side windows (cf. Webster, 2007a, p. 463). On the other hand, the same experts in many cases also deviated from 'orthodox' scientific positions. It is not unusual for professional experts, who earn a living working for corporations or for state authorities that tend to ally themselves with business, to wish to deploy their expertise for tasks that potentially conflict with social goals.

Practicing partisan scholarship does not mean holding to the blindly obedient or dogmatic application of an epistemological tradition. Instead, it entails fostering a methodology that carries the seeds of reflection and of a critical approach towards the methodology itself and towards the established and orthodox views within the controversy under investigation, allowing both researcher and stakeholders to voice criticism. We do not claim a monopolistic relationship with either scientific truth or expertise. In this context, being partisan does not mean lacking valid data, reducing analytical reflexivity, or warring against other kinds of scholarship, but rather making conscious and situated epistemological choices to counter scientific orthodoxy.

This paper is allied with all the STS voices that advocate creating research agendas and choosing epistemic bases so that partisan researchers can introduce research methodologies that succeed in countering epistemic orthodoxy. These agendas accomplish this by taking responsibility for social interests in the production of technoscientific knowledge and by deconstructing powerful actors such as the market, industry, the political economy of research, and mercenary scholars. Systematically supporting partisanship scholarship helps facilitate negotiations over the social and democratic reconstruction of technosciences. 


\section{References}

Allen, G. E. (1987) The role of experts in scientific controversy, in H. Tristam Englehardt and A. Caplan (Eds.), Scientific Controversies: Case Studies in the Resolution and Closure of Disputes in Science and Technology, pp. 169-202 (Cambridge, UK: Cambridge University Press).

Anderson, J., de Coninck, H., Curnow, P., Flach, T., Groenenberg, H., Norton, C., Reiner, D., Shackley, S., Upham, P., Eldevik, F., and Sigurthorsson, G. (2007) The ACCSEPT project: Multidisciplinary Analysis and Gapfilling Strategies (Det Norske Veritas AS).

Anshelm, J. (2000) Mellan Frälsning och Domedag: om KärnkraftensPolitiska Idéhistoria i Sverige 1945-1999 [Between salvation and judgment day: on nuclear powers' political history of ideas in Sweden 1945-1999] (Brutus Östlings Bokförlag Symposion).

Anshelm, J. and Galis, V. (2009) The politics of high-level nuclear waste management in Sweden: confined research versus research in the wild, Environmental Policy and Governance, 19, pp. 269-280.

Ashworth, P. Boughen, N. Mayhew, M. Millar, F. (2010) From research to action: now we have to move on CCS communication, International Journal of Greenhouse Gas Control 4(2), pp. 426-433.

Atterstam, I, (2009) Möjligt att köpa professorstitlar [Possible to purchase professor affiliations]. Svenska Dagbladet, [internet] 6 February. Available at:

http://www.svd.se/nyheter/inrikes/artikel_2418639.svd

[Accessed 10 March 2009].

Bammer, G. and Martin, B. (1992) Repetition strain injury in Australia: medical knowledge, social movement, and de facto partisanship, Social Problems 39(3), pp. 219-237.

Barnes, B. and Bloor, D. (1982) Relativism, rationalism and the sociology of knowledge, in M. Hollis and S. Lukes (Eds.), Rationality and Relativism, pp. 21-47 (Cambridge, MA: MIT Press).

Barnes, C. (1996) Disability and the myth of the independent researcher, In L. Barton and M. Oliver (eds.), Disability Studies: Past, Present and Future, pp. 239-43 (Leeds UK: The Disability Press).

Barnes, C. Mercer G. and Shakespeare T. (1999) Exploring Disability: A Sociological Introduction (Cambridge, UK: Polity Press).

Bennett, U. (2002) Disabled by design, Disability and Society 17(7), pp. 809-823.

Bloor, D. (1976) Knowledge and Social Imaginery (London: Routledge \& Kegan Paul).

Burawoy, M. (2004) The world needs public sociology, Sosiologisk tidsskrift 12(3), pp. 255272.

Burgess, R. (1984) In the Field: An Introduction to Field Research (London: Routledge). 
Callon M. (2003). The increasing involvement of concerned groups in R\&D policies: what lessons for public powers?, in A. Geuna, A. J. Salter and W. E. Steinmueller (Eds.), Science and Innovation, Rethinking the Rationales for Funding and Governance, pp. 30-68

(Cheltenham UK: Edward Elgar).

Callon, M., Barthe, Y., and Lascoumes P. (2009) Acting in an Uncertain World: An Essay on Technical Democracy (London: MIT Press).

Chomsky, N. (1969) Objectivity and liberal scholarship, in N. Chomsky (ed.), American Power and the New Mandarins (New York: Pantheon Books).

Collins, H. (1996) In Praise of futile gestures: how scientific is the sociology of scientific knowledge, Social Studies of Science 32(2), pp. 229-44.

Collins, H. and Evans, R. (2002) The third wave of science studies: studies of expertise and experience, Social Studies of Science 26(2), pp. 235-96.

Collins, H. and Evans, R. (2003) King Canute meets the Beach Boys: responses to the third wave, Social Studies of Science 33(3), pp. 435-452.

de Coninck, H. (2008) Trojan horse or horn of plenty? Reflections on allowing CCS in the CDM, Energy Policy 36(3), pp. 929-936.

Engelhardt, T. H. Jr and Caplan A. L. (eds.) (1987) Scientific Controversies: Case Studies in the Resolution and Closure of Disputes in Science and Technology (Cambridge University Press).

European Commission (2008) Directive of the European Parliament and of the council: on the geological storage of carbon dioxide. COM(2008) 18 final 2008/0015 (COD).

Epstein, S. (1995) The construction of lay expertise: AIDS activism and the forging of credibility in the reform of clinical trials, Science, Technology, \& Human Values 20(4), pp. 408-37.

Ferrell, J. (2009) Against method, against authority...For anarchy, in R. Amster, A. DeLeon, L. Fernadez, A. J. Nocella II and D. Shannon (Eds.), Contemporary Anarchist Studies, pp. 73-81 (New York: Routledge).

Feyerabend, P. K. (1975) [2010] Against method: Outline of an Anarchistic Theory of Knowledge (London: Verso).

French, S. and Swain, J. (1997) Changing disability research: participating and emancipatory research with disabled people, Physiotherapy 83(1), pp. 26-32.

Foucault, M. 2003. Society Must Be Defended: Lectures at the Collége de France 1975-1976, in M. Bertani and A. Fontana (Eds.) (New York: Picador). 
Fujimura, J. (1991) On Methods, ontologies and representation in the sociology of science: where do we stand?, in D. Maines, (ed.) Social Organization and Social Process: Essays in Honor of Anselm Strauss, pp. 207-49 (New York: De Gruyter).

Funtowicz, S. and Ravetz, J. (1993) Science for the post-normal age, Futures, November, pp. $735-755$.

Galis, V. (2006) From Shrieks to Technical Reports: Technology, Disability and Political Processes in Building Athens Metro, Linköping University Studies in Arts and Science No. 374, PhD thesis, Linköping University, Linköping, Sweden.

Gouldner, A. (1976) The Dialectic of Ideology and Technology (London and Basingstoke: The Macmillan Press LTD).

Greenwood, D. J. and Levin, M. (2007) Introduction to Action Research: Social Research for Social Change (London: Sage).

Hansson, A. (2008) Kolets Återkomst: Koldioxidavskiljning och Lagring i Vetenskap och Politik. [The Return of Coal: Carbondioxide capture and storage in science and politics, Linköping University Studies in Arts and Science No. 436, PhD thesis, Linköping University, Linköping, Sweden.

Haraway, D. (1997) Modest_Witness@Second_Millenium.Femaleman_Meets_Oncomouse ${ }^{\text {tm }}$ (New York: Routledge).

Haraway, D. (2001) Situated Knowledges: the science question in feminism and the privilege of partial perspective, in M. Lederman and I. Bartsch, (Eds.), The Gender and Science Reader, pp. 169-188 (London: Routledge).

Harding, S. (2001) Feminist standpoint epistemology, in M. Lederman and I. Bartsch, (Eds.), The Gender and Science Reader, pp. 145-168 (London: Routledge).

IPCC (2005) Carbon dioxide capture and storage. IPCC special report on carbon dioxide capture and storage. Prepared by the Working Group III of the Intergovernmental Panel on Climate Change, (Cambridge, USA: Cambridge University Press).

Jasanoff, S. (1996) Beyond epistemology: relativism and rngagement in the politics of science, Social Studies of Science 26(2), pp. 393-418.

Jasanoff, S. (1997) NGOs and the environment: from knowledge to action, Third World Quarterly, 18(3), pp. 579-594.

Jasanoff, S. (2004). Science and citizenship: a new synergy, Science and Public Policy, 31(2), pp. 90-94.

Latour, B. (1999) On recalling ANT, in Law J. and Hassard J. (Eds.) Actor Network Theory and After, pp. 15-25 (Oxford: Blackwell Publishers).

Longino, H. E. (1990) Science as Social Knowledge: Values and Objectivity in Scientific Inquiry (Princeton, NJ: Princeton University Press). 
Malone, E. L. Dooley, J. J. Bradbury. J. A. (2010) Moving from misinformation derived from public attitude surveys on carbon dioxide capture and storage towards realistic stakeholder involvement, International Journal of Greenhouse Gas Control 4(2), pp. 419-425.

Mander, S. and Gough, C. (2006) Media framing of new technology: the case of carbon capture and storage, Proceedings 8th International Conference on Greenhouse Gas Technology, 2006, Trondheim, Norway.

Martin, B. (1993) The critique of science becomes academic, Science, Technology, and Human Values, 18(2), pp. 247-259.

Martin, B. (1996) Sticking a needle into science: the case of polio vaccines and the origin of AIDS, Social Studies of Science 26(2), pp. 245-276.

Martin, B. (1998) Captivity and commitment, Technoscience 11(1), pp. 8-9.

Martin, B. (2003) Citizen advocacy and paid advocacy: a comparison, Interaction 17(1), pp. $15-20$.

Marres, N. (2007) The issues deserve more credit: pragmatist contributions to the study of public involvement in controversy, Social Studies of Science 37(5), pp.759-780.

May, T. (1994) The Political Philosophy of Poststructuralist Anarchism (University Park, Pennsylvania: The Pennsylvania State University Press).

McConkey, J. (2004) Knowledge and acknowledgment: 'epistemic Injustice' as a problem of eecognition, Politics 24(3), pp. 198-205.

McGrath, P. J. (2002) Scientists, Business, and the State, 1890-1960 (Chapel Hill: University of North Carolina Press).

Melissa, L. Scoones, I. and Wynne, B. (Eds.) (2005) Science and Citizens: Globalization \& the Challenge of Engagement (London, UK: Zed Books).

Moore, M. Beazley, S. and Maezler, J. (1998) Researching Disability Issues (Buckingham: Open University Press).

Nelkin, D. (ed.) (1992) Controversy: Politics of Technical Decision (Beverly Hills: Sage).

Nilsson T. and Atterstam I. (2009) Högskolor bryter mot reglerna [Universities break the law]. Svenska Dagbladet, [internet] 5 February. Available at:

http://www.svd.se/nyheter/inrikes/artikel_2424189.svd

[Accessed 10 March 2009].

Nowotny, H. (2007) How many policy rooms are there? Evidence-based and other kinds of science policies, Science, Technology and Human Values 32(4), pp. 479-490.

Nowotny, H., Scott, P. and Gibbons M. (2001) Re-thinking Science: knowledge and the public in an age of uncertainty (Cambridge: Polity Press). 
Page, S. C. Williamson, A. G. Mason, I.G (2009) Carbon capture and storage: fundamental thermodynamics and current technology, Energy Policy 37(9), pp. 3314-3324.

Rabeharisoa, V. and Callon, M. (2002) The involvement of patients' associations in research, International Social Science Journal 54(171), pp. 57-65.

Ramirez, C. A., Hoogwijk M., Hendriks C., and Faaij A., (2008) Using a participatory approach to develop a sustainability framework for carbon capture and storage systems in the Netherlands, International Journal of Greenhouse Gas Control (2), pp. 136-154.

Reason P. and Bradbury, H. (2001) Handbook of Action Research (London: Sage).

Reiner, D. M. (2008) A Looming Rhetorical Gap: A Survey of Public Communication Activity for Carbon Dioxide Capture and Storage Technologies. Electricity Policy Research Group, (Cambridge, UK: University of Cambridge). Available at:

http://www.electricitypolicy.org.uk/pubs/index.html.

Richards, E. (1996) (Un)boxing the monster, Social Studies of Science 26(2), pp. 323-356.

Rochon, E. (2008) Why Carbon Capture and Storage Won't Save the Climate (The Netherlands: Greenpeace International).

Rose, H. and Rose, S. (Eds.) (1976) The Radicalization of Science: Ideology of/in the Natural Sciences (London and Basingstoke: The Macmillan Press).

Rose, H. and Rose, S. (Eds.) (1979) Ideology of/in the Natural Sciences (Cambridge , MA: Schenkman Publishing Co).

Scott, P. Richards, E. and Martin, B., (1990) Captives of controversy: The myth of the neutral social researcher in contemporary scientific controversies, Science, Technology and Human Values 15(4), pp. 474-494.

Tjernshaugen, A. (2008) Political commitment to $\mathrm{CO}_{2}$ capture and storage: evidence from government R\&D budgets, Mitigation and Adaptation Strategies for Global Change 13(1), pp. 1-21.

Webster, A. (2007a) Crossing boundaries: social science in the policy room, Science, Technology and Human Values 32(4), pp. 458-478.

Webster, A. (2007b) Reflections on reflexive engagement: response to Nowotny and Wynne, Science, Technology and Human Values 32(5), pp. 608-615.

Woodhouse, E. (2005) (Re)constructing technological society by taking social construction even more seriously, Social Epistemology 19(2-3), pp. $199-223$.

Woodhouse, E. Hess, D. Breyman, S. and Martin, B., (2002) Science studies and activism: possibilities and problems for reconstructivist agendas, Social Studies of Science 32(2), pp. 297-319. 
Wynne B. (1989) Sheep farming after Chernobyl: a case study in communicating scientific information, Environment 31(2), pp. 10-15, 33-9.

\author{
Wynne B. (2007) Dazzled by the mirage of influence?: STS-SSK in multivalent registers of \\ relevance, Science, Technology \& Human Values 32(4), pp. 491-503.
}

\footnotetext{
${ }^{\mathrm{i}}$ Martin notes that those possessing more resources can better denigrate their opponents by attributing motivesimplicitly assumed to be unscientific - to them while not acknowledging their own (personal communication, Brian Martin, August 2009).

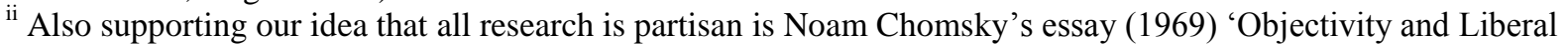
Scholarship', in which the author deconstructs the historiography of the Spanish Civil War in the 1930s by American liberal historians. Chomsky shows how American liberal scholars forcefully opposes mass movements and social change that escape the control of privileged elites, with no attempt to hide their personal or ideological commitments in favor of liberal democracy.

iii See also Scott et al. (1990).

iv See, for example, Brian Martin's study of polio vaccines and the origin of HIV/AIDS; Martin states that his engagement in the controversy played some role in shaping the course of the debate (Martin, 1996, p. 256).

${ }^{v}$ Martin (2003) has made a very interesting distinction between paid advocacy and citizen advocacy that can also be applied in our analysis of partisan versus mercenary scholarship.

vi The table is inspired by Martin (1996).

vii Both cases entail elements of partisan agendas. However, the first case can be characterised mainly as de facto partisanship regarding CCS, while the second is openly aligned with the interests of the Greek disability movement.

${ }^{\text {viii }}$ We are aware that there is a long history of university funding (not only in Sweden) by corporations, the military, and government bodies that can be associated with what we call mercenary scholarship. Nevertheless, we are unaware of studies that critically discuss this phenomenon.

${ }^{\text {ix }}$ It is worth noting here that I do not treat disabled people as a homogenous social group. One could divide the disabled according to type of disability, for example, difficulty walking, moving about, seeing or hearing, communicating with people, and learning as well as ill health. A different taxonomy of disabled people includes those individuals with physical or mental disabilities, as well as those who face mobility difficulties, such as the elderly, pregnant women, youngsters, and individuals with disproportionate body features. It is important to mention that when talking about disabled people in this text, I am referring to individuals who, quite apart from their bodily characteristics, belong to the so-called disability movement. By this I mean people who represent a wide category of individuals who face various disabilities and engage themselves in political struggles against exclusion and discrimination regarding their participation in society, in terms of accessibility to the urban environment, political power, labour, economic support, etc.
} 